\title{
ERRATUM
}

\section{Dagmar Orth}

\section{Human gene mutations}

\section{Hum Genet (2005) 116:533-545}

In some of the Human Gene Mutations published in 116:533-545 the authors were listed in the wrong order.

For the seven mutations with the Accession Numbers Hs0400023, Hd040032, Hd040033, Hd040034,

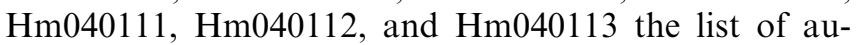
thors should read:

R. Otway, N. Tetlow, J. Hornby, W.F. Doe, M.R.J. Kohonen-Corish

For Accession Number: Hm040133 it should read:

Susanne F. de Haar, Maziar Mir, Melanie Nguyen, Bahram Kazemi, Golam Hosein Ramezani, Vincent Everts, Wouter Beertsen

And the affected codon is codon 405 and not codon 7

The online version of the original article can be found at http:// dx.doi.org/10.1007/s00439-005-1283-2

D. Orth

Springer-Verlag, Heidelberg, Germany 